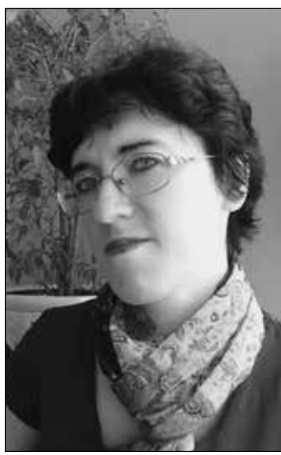

https://doi.org/10.24101/logos.2016.02

RÜTA BAGDANAVIČIÜTE்

Klaipedos universitetas, Lietuva

Klaipeda University, Lithuania

\title{
INTERSUBJEKTYVI HERMENEUTINE SPRENDIMO ETIKA: TARP J. HABERMASO IDEALIOS KOMUNIKACIJOS IR M. FOUCAULT GYVYBINGOS DIALOGO ITAMPOS
}

\author{
Intersubjective Hermeneutical Ethics of Decision: Between Habermas' \\ Ideal Communication and Foucault's Vital Tension in a Dialogue
}

\author{
SUMMARY
}

The text analyses intersubjective hermeneutical decision ethics based on dialogue. Dialogue is highlighted with an emphasis on dialogue in the context of today's nihilistic vocation of hermeneutics (G. Vattimo). The question is about the extent of the idea of hermeneutical dialogue and what transformations it is experiencing. Standing critically on the grounds of Derrida's ethics of absolute hospitality, the topicality of decision ethics (R. Kearney) is also highlighted in the context of current society. This theory suggests an ethics of unradical hermeneutical decision, which enacts some decisions about the other, However, it conceives the interpretability of these decisions. The article refers to J. Habermas' ideal communication based on a rational mind according to democracy ideals. But rational communication is distorted by various power practices in our postdemocratical context, and these practices are not defeated by rational reflection. When faith is lost for the possibility of positive dialogue and mutual understanding, then there arises the danger of relativism and self-destructive fragmentation. A dynamic social dialogue which raises the tension between dialogue and power relationships is more adequate to the conditions of today's postdemocracy. This tension is analyzed in relation to N. Davey's hermeneutical unquiet understanding and G. Vattimo's nihilistic vocation of hermeneutics.

\section{SANTRAUKA}

Tekste svarstoma intersubjektyvi, dialogu paremta hermeneutinė sprendimo etika. Išryškinamas hermeneutikos dialogiškumo matmuo ir kartu akcentuojamas pasikeitęs to dialogiškumo pobūdis šių dienų herme- 
neutikos, pajutusios „,nihilistinį pašaukimą“ (G. Vattimo), kontekste. Keliamas klausimas, kiek hermeneutinio dialogo ideja aktuali socialiniame kontekste ir kokias transformacijas ji patiria šiandien. Kritiškai atsispiriant nuo Derrida absoliutaus svetingumo etikos, išryškinamas hermeneutinės socialinės sprendimo etikos (R. Kearney) aktualumas šių dienų socialinių santykių kontekste. Siūloma neradikalaus hermeneutinio sprendimo etika, leidžianti priimti tam tikrus sprendimus apie kitą, tačiau kartu suvokianti tų priimamu sprendimų interpretaciškumą. Tokia etika socialiniame kontekste siejama su J. Habermaso idealios komunikacijos, paremtos komunikaciniu protu, filosofija, atitinkančia demokratijos idealą. Kartu parodoma, kad tokia autonomiška, sutarimų link kreipianti racionali komunikacija mūsų postdemokratiniame kontekste nuolat iškraipoma įvairių galios praktikų, nęiveikiamų racionalios refleksijos judesiu. O praradus tikèjimą galimybe pozityviai susišnekèti, kartais net šnekètis, iškyla reliatyvizmo, savidestruktyvaus fragmentizmo grèsmè. M. Foucault atviro dialogo samprata (Ch. Falzono akimis) atskleidžiama kaip alternatyva tokiam fragmentizmui. Toks dinamiškas socialinis dialogas, iškeliantis įtampą tarp dialogo ir galios santykių, atskleidžiamas kaip gerokai artimesnis šiandieninei postdemokratijai. Ši j̨tampa analizuojama siejant ją su N. Davey'aus hermeneutiniu neramiu mąstymu ir G. Vattimo hermeneutikos nihilistiniu pašaukimu.

\section{IVADAS}

Šiame tekste svarstoma intersubjektyvi hermeneutinè sprendimo etika, keliant klausima, ar hermeneutinio dialogo ideja yra pritaikoma šiandieninių socialiniu santykiu kontekste - gal ji virsta teorine utopija, nukreipta i nepasiekiamą ateiti, neigyvendinama socialinès realybės plotmèje? Kita vertus, kinta pats dialogo pobūdis keičiantis hermeneutikai: šiandieninè hermeneutika, kuri post- (ar postpost...) moderniajame mažuju pasakojimu ${ }^{1}$ kontekste neatskiriamai susijusi su dekonstrukcine skirtimi, atsisako iccentrinès orientacijos i bendrą dialogiškai pasiekiamą supratimą ir universalias tiesas. Ji labiau siejama su nihilistini $p a-$ šaukima ${ }^{2}$ atliepiančiomis interpretaciju interpretacijomis, nepretenduojančiomis atitikti tikrosios tiesos, verčiau besimègaujančiomis laisve nevaržomai interpretuoti išryškinant skirtis.

Reprezentatyvūs yra 1981 m. ìvykę neimanomi Gadamerio ir Derrida debatai, išskleidžiantys ittampą tarp hermeneutinio dialogo siekio ir dekonstrukcinės jo negalimybès. Čia Gadameris, maksima- liai išplèsdamas savo supratimo ribas, siekia bendro supratimo, o Derrida priešingai: vadovaujasi išankstine nuostata skaldyti bet kokius bendro supratimo branduolius interpretuodamas išcentriškai. Čia išryškejja Gadamerio (kartu su M. Heideggeriu) atviras, kartais beveik pranokstantis save, supratimas, priimantis kai kuriuos dekonstrukcijos elementus ị hermeneutika, patvirtindamas tezę, kad „filosofinè hermeneutika, užuot buvusi opozicija dekonstrukcijai,

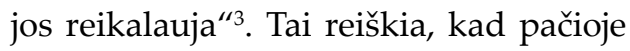
hermeneutikoje glūdi prielaidos vis labiau plèstis, siekiant giliausiu savo pačios akstinu išpildymo, nesusitapatinti tik su bendros stabilios prasmés siekiu. Taigi natūraliai krypstama prie radikaliu išcentrintų interpretacijų, parodančių, kaip „dekonstrukcija yra „hermeneutiška“ ir kaip hermeneutika "dekonstrukciška" ${ }^{\prime 4}$, atveriančiu ",hermeneutikos bei dekonstrukcijos giminingumą ${ }^{45}$ : „Hermeneutika su dekonstrukcija praranda savo nekaltumą ir tai darydama tampa dar ištikimesnè savo paskirtam keliui, 
kuris [...] reiškia pasilikti ištikimam gyvenimo sudètingumui."

Tokia kryptis, toks kelias skatina ir hermeneutinès dialogo sampratos kaita, jos plètimąsi: nuo griežto esencialaus ịsitikinimo, kad dialogu būtina pasiekti aiškius bendrus sutarimus, galutines uždaras tiesas, judama prie dialogo kaip atviro, dinamiško santykio su kitu, kai svarbiausia - būti pokalbyje, bet nebūtinai sutarti, kuriame ",aš" gali būti kito išmuštas iš savivokos centro ir išprovokuotas permąstyti save iš naujo. Tai tam tikra prasme save pranokstantis dialogas. Jis kyla iš pačios hermeneutikos, pajutusios dekonstrukcini stimula, esmès.

Tokia ivvairialype, besitransformuojanti hermeneutinio dialogo samprata reikšmingai atsispindi ir socialiniame kontekste, kuriame skleidžiasi intersubjektyvi etika.

Net priešinantis bet kokiems bendrumams, socialinių santykių kontekste, kur interpretacija visuomet susijusi su galia, neegzistuojama atomizuotų skirčiu būklejje. Net atsidavus nevaržomai laisvei išcentriškai interpretuoti, neišvengiama klausimo: „Kurlink kreipia šios interpretacijos, virtusios gausybe mažuju pasakojimu?"“ Net ir vengiant ribojančiu sprendimu apie kita, socialinejje sferoje šie sprendimai neišvengiami, jie priimami nuolat - tik hermeneutinejje dialogo su kitu situacijoje priimami sprendimai nèra tokie radikalūs kaip esantys anapus šios dialogo situacijos.

Čia galètume kritiškai atsispirti nuo Derrida absoliutaus svetingumo etikos.

\section{ABSOLIUTAUS SVETINGUMO ETIKA IR SOCIALINĖ SPRENDIMŲ BÜTINYBĖ: NERADIKALŪS HERMENEUTINIAI SPRENDIMAI}

Leviniškąja mąstymo kryptimi pasukęs Derrida formuluoja svetingumo, pranokstančio ,istatymo svetinguma, siejamą su teise ar pareiga ${ }^{47}$, sutraukančio socialines teisines, sprendimais apie kitus gristas svetingumo konvencijas, etiką: „Svetingumo įstatymas, neatidèliotinas įsakymas, kuris valdo bendrą svetingumo koncepta, pasirodo kaip paradoksalus įstatymas, iškrypęs ir iškraipantis. Regis, juo vadovaujantis, absoliutus svetingumas turètu prieštarauti svetingumo, kaip teisès ar pareigos, i̇statymui..." ${ }^{8}$ Dekonstrukcijos filosofas atsisako ivesti skirtis tarp skirtingų kitu, nes čia etinis santykis su kitu yra pirmiau už sprendima. Taigi išryškejja asimetriškas santykis su kitu, kuris įsiveržia kaip ,istatymas be istatymo", reikalaujantis besąlygiškai jam paklusti: „Namų šeimininkas privalo svetingai priimti užsienietí, nepažistamajji, svečią, nekeldamas jam jokių sąlygu, taip pat nekreipdamas dèmesio i tai, kad jis niekada nebuvo kviestas. ${ }^{\prime 9}$

Toks absoliutus svetingumas, kaip matome, vita activa plotmèje paradoksaliai virsta prievartiniu kito įsiveržimu. Tokia Derrida etika, kurią jis sieja ne tik su eschatologine, religine, bet ir su socialine politine plotme, atrodo idomi ir kartu kelianti abejoniu šiandieniniame demokratijos - nors ir labai trapios, jau pasiekusios postdemokratijos pakopa, kontekste. 
Galime šią teoriją pailiustruoti itin nestabilaus šiandienos socialinio gyvenimo realijomis. Konkrečiau pažvelgę i socialini konteksta, matome, kad liberalios Europos pasaulis susiduria su visai kitokio nei „vakarietiškasis“ mentaliteto islamišku pasauliu. Šiandien ta sandūra yra itin suintensyvejjusi ir suradikalejusi. Islamiškasis kitas, reprezentatyviausiai išreiškiamas "Islamo valstybès" religiniu îsitikinimu pagrindu izsteigtos politinès valdžios, - teroristiškai įsiveržia ì Europą.

Tiesa, pavojinga būtų suabsoliutinti „Islamo valstybę" iki viso islamiškojo pasaulio, nes teroristinius aktus rengia pavieniai radikalizuoti asmenys - džihadistai. Greta jų matome milijonus taikių musulmonu, tarp ju pasitaiko netgi liberalių, tokių kaip Londono meras S. Kahnas, ginantis gejjų ir lesbiečiuc santuokas. Tačiau būtent tie ultraradikalizuoti vienetai griauna taikų sambūvị su Vakarais neleisdami įvykti tarpcivilizaciniam dialogui, maža to, sejja nesaugumo ir baimès atmosferą, žudydami taikius žmones kasdienėse situacijose, kai, regis, mažiausiai galima to tikètis...

Tai liudija pastaruoju metu surengta ištisa teroristinių aktų serija: $2005 \mathrm{~m}$. liepos 7-ąją ivykdytas mirtininkų išpuolis Londone; 2015 m. sausio 7-ąją Prancūziją sukrètė ginkluota ataka prieš satyrinio žurnalo "Charlie Hebdo" redakciją dèl Mahometo karikatūrų, palydima žodžių "Alach akbar"; tų pačių metų lapkričio 13-ąją pasipylė teroristiniai išpuoliai viešosiose Paryžiaus erdvėse: prie futbolo stadiono, koncertų rūmų, kavinių, restoranų; 2016 m. kovo 22-ąją aidejjo sprogimai Belgijos oro uoste, metro stotyje, netoli Europos Sajungos institucijų; šių metų liepos 14-ąja, Prancūzijai švenčiant Bastilijos diena, Nicos kurorte i minią rěžėsi teroristo sunkvežimis; liepos 26-ąją peiliais ginkluoti „,kariai“ i̊siveržè ị Prancūzijos bažnyčia, vykstant pamaldoms, ir nužudè 84-erių taikų katalikų kunigą...

Matome, jog kiti - islamiškieji radikalai - tokiais ekstremaliais veiksmais įsiveržę drastiškai griauna Europos liberalujji (arba quasiliberalųji) diskursa, smurtu reikalaudami besalygiško paklusnumo - deridiškosios absoliutaus svetingumo etikos. Tokia etika atsisako paisyti žmogaus teisių - neatsitiktinai T. Kavaliauskas diagnozuoja „,̌̌mogaus teisių tragediją po Nicos palmių šakelèmis" ${ }^{\prime 10}$, griežtai iškeldamas šių teisių, kilusių iš humanistinès sekuliarios, taigi „bedieviškos“ tradicijos ${ }^{11}$, universalumo klausimą.

Vis dèlto kai kurie Europos intelektualai palaiko absoliutaus svetingumo etikq. Antai publicistas Timotis Gartonas Ashas, teigiantis, kad Europos problema jam yra ne musulmonai, o europiečiai, kuriems vis dar trūksta svetingumo, nes neleidžia musulmoniškiesiems bendrapiliečiams pasijausti kaip namie ${ }^{12}$. Vadovaujantis tokia logika, tektų pripažinti, kad „dèl žudynių Niujorke, Londone ir Madride kalti galiausiai esame patys, nes dar nesame pakankamai atviri ir svetingi..."13 Kita vertus, vis labiau plinta ir priešinga nuostata. Štai prancūzų filosofas Pascalis Bruckneris kaltina eseistą T. G. Ashą kartu su Ianu Buruma propaguojant multikultūralizma, prilygstanti apartheidui, arba ,,antirasistų rasizmui ${ }^{\prime 14}$.

Nenukrypstant $i$ tokias radikalias pozicijas, vis dèlto naivu atrodo tikètis, kad tokia absoliutaus svetingumo etika čia at- 
skleidžiamoje socialinėje politinėje plotmejje, kurioje „absoliuti netolerancija susitinka su savižudišku svetingumu“"15, bus igyvendinta. Kitaip pasyvioji, atsisakanti apsispręsti, pusè tiesiog mazochistiškai pasmerktų save išnykti tapusi to kito, aktyviai primetančio savo sprendimus, ikaitais. Priemusios „pasidavimą ${ }^{\mu 16}$ galiausiai „civilizacijos nusižudo pačios ${ }^{\prime \prime 17}$.

Pasitelkime R. Kearney pozicija, kuris kritiškai žvelgia i deridiškąją absoliutaus svetingumo etika, reflektuodamas ją iš socialinès sprendimo etikos pozicijų ${ }^{18}$. Iš šiu poziciju kelia problema, kaip atskirti skirtingas kitybès formas ${ }^{19}$ : kaip tuomet "galime atskirti šventas nuo nešventų sielų; kaip galime skirti taikos skleidejus nuo teroro ir destrukcijos skleidejju? ${ }^{\prime 20}$ Ši diferenciacija įtraukia mūsų sprendimą apie kitą prieš santyki su tuo kitu. Taigi tai skirtingų savo esme etikų susidūrimas.

Socialiniame kontekste, politinių manipuliacijų tinkle, bent dalinè sprendimo etika yra neišvengiama, o grynoji absoliutaus svetingumo etika prilygsta ,,indiferencijos etikai" ${ }^{21}$ ir yra netgi pavojinga. Čia aktualesnè, regis, būtų hermeneutinè pozicija, kai nenukrypstama nei į Derrida absoliutaus svetingumo etika, nei į radikalų sprendimų priemimą: viena vertus, raginama nepriimti radikalių sprendimu traktuojant kitą ne objektiškai, o dialogiškai, tame dialoge perinterpretuojant turimas nuostatas apie kita kita vertus, neliekama neapsisprendžiamumo būklèje. Hermeneutikoje siūloma neradikalaus sprendimo etika, atsisakanti juodos ir baltos spalvų. Tai yra leidžianti priimti tam tikrus sprendimus apie kitą arba pripažistanti tų sprendimų neišvengiamuma, tačiau kartu suvokianti tu priimamų sprendimų interpretaciškumą - tai, kad jie „,niekuomet nepakyla virš hermeneutinio interpretaciju pliuralumo imperatyvo ${ }^{\prime \prime 22}$.

Žinoma, tokia etika įmanoma tik jei pavyksta pasiekti bent minimalią santykiu simetriją - ne tik absoliutaus svetingumo etika, bet ir neradikalaus sprendimo etika, susidūrusi su pernelyg radikaliais sprendimais, pasmerkiama žlugti. Tai galime numanyti iš pateikto pavyzdžio apie islamiškajji kitą. Europa, patyrusi itin radikalius išpuolius, dar bando byloti neradikaliai liberaliu balsu, laikydama ji savo stiprybe. Tačiau vis dažniau pasigirsta vertinimu apie to balso silpnuma, gramzdinantị i slogią „,liberalizmo tylą“2 ${ }^{\prime 23} \ldots$

Tokia situacija pastaruoju metu išprovokuoja taip pat radikalius antiislamiškus europiečiu judèjimus, tokius kaip Rytų Vokietijoje užgimusią "Pegidą", Angelos Merkel pasmerktą už ,,ksenofobiškumą, rasizmą “24. Vokietijos kanclere ragino atverti Vokietiją musulmonu pabėgèlių srautams, nors prieš šešerius metus teigè, kad multikultūralizmas, neatskiriamai susijęs su imigracija, Vokietijoje žlugo ${ }^{25}$. Toks savotiškas blaškymasis tarp "svetingumo kultūros" (culture of welcome) ir "neapykantos kultūros" (culture of hate) išreiškia baimę, nežinomybę islamiškojo kito akivaizdoje: viena vertus, jaučiama, kad jei Europa ị išpuolius reaguos taip pat radikaliai, tai stums $i$ karo būklę, kai neliks jokios neradikalios hermeneutinès etikos galimybès, kita vertus, suvokiama, kad neradikalus balsas gali būti (ir dažnai būna) neišgirstas.

Be to, nerimą sustiprina byranti Europa $^{26}$, eižejantys jos pagrindai, radikalizuoto islamiškojo kito akivaizdoje atsi- 
veriančios skirtys tarp Senosios ir Naujosios Europos, galiausiai kylanti grèsmè, kad socialinis kontraktas, laiduojantis Europos šalių vienybę, bus sulaužytas, vargiai galint atsakyti i klausimą, kas sudaro europietiškumo esmę, kai vienija tik bendros baimès ${ }^{27}$...

Taigi, kaip matome, skirčių vis daugèja, o konsensusas tampa problema, gal net iššūkiu nūdienos socialinèje terpèje. Vis dèlto siekti tam tikrų, kad ir likvidžių, konsensusų, rortiškųjų solidaru$\mathrm{muc}^{28}$ socialinèje plotmëje neišvengiama, socialinio kontrakto, nors ir skilinejjančio, tema lieka aktuali kalbant apie socialinį bendrabūvì, jei nesusitaikome, kad jis virstų anarchjiška karo būkle. $\mathrm{O}$ bet koks kontraktas imanomas tik kaip intersubjektyvaus hermeneutinio dialogo pastanga sušvelninant savo radikalumus, pripažistant, kad „nèra tokio išorinio ar nesąmoningo kito [...], kuris nebūtų galimas nors minimaliai interpretuoti paties, interpretuojamas daugybe skirtingų būdư, nors ir nè vienas iš jų nėra absoliutus, adekvatus arba išsemiantis. Kitas nėra taip traumiškai susvetimejjęs, kad laikytų mane įkaitu; taip pat nèra taip varganai nusižeminęs, kad paverstų mane valdingu. Etiniame santykyje aš nesu nei ponas, nei vergas, Aš esu pats prieš kitą pati..." Taip interpretaciškai balansuojama tarp aš ir kito, kur ,,kitas nèra nei per arti, nei per toli, nei per daug artimas, nei per daug svetimas“, kur jis "nesuniveliuojamas to paties ir taip pat neištremia savęs iz nepasiekiamą kitybę “29.

Šiandien apie toki dinamiška, nepretenduojanti i užtikrintumą dialoga kuriuo paremta intersubjektyvi hermeneutinè etika, galime kalbèti kaip apie praktikoje sunkiai realizuojama, bet neišvengiamą siekiamybę. Tiesa, reikètų pridurti, kad ji i̇manoma tik bent teoriškai demokratiją išpažistančiose šalyse, kur galimi nors iš dalies simetriški santykiai (drastiški radikalumai nužudo bet kokią dialogo galimybę). Taigi svarstant tokią dialoginę etiką turimas omenyje demokratiškas ir liberalusis, tiksliau, postliberalusis europietiškasis kontekstas, kuriame, kaip matėme, socialinis konsensusas taip pat pradeda eižèti.

\section{SOCIALINIU DIALOGU GRILTA ETIKA: NUO RACIONALIOS KOMUNIKACIJOS IDEALO IKI IŠCENTRINTOS DIALOGO ITAMPOS}

Toks intersubjektyvus dialogas dažnai pasitelkiamas kaip demokratinis socialinių santykių modelis. Idealus tokio modelio variantas sukuriamas Gadamerio hermeneutinę dialogo filosofiją jungiant su J. Habermaso idealios komunikacijos teorija. Pastaroji traktuotina kaip Gadamerio dialogo filosofijos tęsinys socialinių santykių kontekste, perkeliantis iš filosofinių vita contemplativa gelmiu i vita activa - socialinių santykių plotmę. Nors šios filosofijos kiek skiriasi prielaidų bei racionalumo vaidmens traktavi$\mathrm{mu}^{30}$, tačiau joms bendras dialogo, tapatumo, bendros prasmès siekis, kreipiantis interpretaciją įcentriškai.

Habermasiškasis dialogas, kaip socialinius sprendimus igalinantis konsensusas, plètojasi per intersubjektyvias kalbines praktikas. Jis paremtas komunikaci- 
niu racionalumu ${ }^{31}$, kuris gerokai skiriasi nuo karteziškojo, linkusio ị monologa, yra išvaduotas iš ,,transcendentalinio subjekto kalejimo" ${ }^{\prime 32}$. İžvelgiama komunikacinè racionalumo prigimtis ir kartu suvokiamas pamatinis kalbos socialumas ieškoma „,komunikacinio proto pėdsaku, issišaknijusių komunikacijos procesuose, vykstančiuose pačiose socialinėse praktikose $^{\prime \prime 33}$. Tikima kritiniu tokio racionalumo potencialu deskriptyviai kreipti susišnekejjimo link: „,Visos socialinès tvarkos ir institucijos yra paremtos protu. Mes net nesirūpintume eiti i teismą dẻl sunkiai išsprendžiamų konfliktu, jei nesitikètume daugiau ar mažiau sąžiningo teismo. Mes nedalyvautume demokratiniuose rinkimuose, jeigu nemanytume, kad kiekvienas balsas „užsiskaito“. ${ }^{34}$

O tai, kas netelpa i i šio susišnekejjimo rẻmus, iš jų vietomis išsiveržiantis kito kitoniškumas, primenantis apie neivveiktas prielaidas, ir pretenzija dominuoti, igyti galia, traktuojama kaip nereikšminga to savo idealybès rate besisukančio konsensuso liekana, kurią galima įveikti tiesiog vis labiau įsisukant i šş rata, t. y. skaidrinant protą. Toks komunikacinio proto galia paremtas dialogas, vykstantis tarp brandžiu, t. y. kritiškai racionaliai mąstančių, asmenybių, galètų būti idealios demokratijos modeliu.

Tiesa, pats J. Habermasas pripažista, kad tikejimas tokiu protu gristu susišnekejjimu yra idealistinis, tačiau kartu tvirtina, kad jis būtinas žvelgiant iš dalyvių perspektyvos.

Vis dèlto atrodo, kad šiandien ši būtinybė neretai pažeidžiama. Racionalumu grịsta tvarka dažnai pasirodo savi/ apgaulè - po racionaliu paviršiumi kun- kuliuoja egzistenciniu patirtiniu prielaidu vandenynas, iš kurio ir iškyla tai, ką ir kaip mes renkamès racionaliai paaiškinti. Racionalumas niekada nèra grynas, nors ir kurtu tokią iliuzija, jis neišvengia subjektyvumo priemaišų. Perfrazuojant prancūzų filosofą Pierre'ą Bourdieu, tam tikro jègų santykio, simbolinio socialinès tvarkos smurto ${ }^{35}$ negali panaikinti joks kalbejjimasis - kad ir kaip stengtumèmès išgryninti kalbèjima, visada yra svarbu ne tik $k a$, bet ir kas kalba.

Taigi mes einame i teismą, žinodami, kad sqžiningus, teisingus sprendimus dažnai lemia ne grynasis teisingumo jausmas, nešališkai prabylanti sąžinė, o subjektyvūs konjunktūriški sutarimai, išankstinès nuostatos, galu gale kapitalistinèje šiandienos visuomenëje viskas, net principai, paklūsta prekinei logikai... Taip pat demokratiniuose rinkimuose gal ir kiekvienas balsas „užsiskaito“, bet, „užskaičius" tuos balsus, "išrinktieji“ atitrūksta nuo juos rinkusiuju, savaip persitvarkydami mūsų pernelyg likvidžiame nuolat besimaišančių politinių srovių kontekste, kuriame dominuoja toli gražu ne racionalumas, o rafinuoti (o kartais ir nelabai) galių santykiu žaidimai.

Bet, regis, ir aptariamas vokiečių filosofas pripažista, kad ,'mūsų kapitalistinès demokratijos traukiasi iki tik fasadiniu demokratiju“. Tik jis po to sako, kad "tokia raida reikalauja mokslinio švietimo“36. Mes keltume klausimą: ar toks švietimas gali pagelbèti mūsų kontekste? Ar racionalumo skaidrinimas gali mus vesti prie teisingumo principais gristo sutarimo? Ar galių žaidimai iš principo gali būti ìveikiami tokiu racionalumu, "moksliniu švietimu" - gal tai 
vis dèlto pernelyg idealus tikèjimas, įsukantis i ydingą rata, kuriame jègų santykiai ne ištirpsta, o tik paliekami anapus. Kitaip tariant, nenorima matyti darnų to rato sukimąsi trikdančių galios santykių, užsimerkiama prieš, nepaisant racionalių pastangu, vis labiau trūkinėjančius sutarimų saitus.

Kai esame apraizgyti naujuju mediju produkuojamais hiperrealybès tinklais, atsidūrę „nuo erdvèlaikio nepriklausomoje viešybejje ${ }^{\prime 37}$, kur viskas tarsi yra čia-ir-dabar, bet kartu neapčiuopiama, likvidu, fragmentiška, ir socialiniai santykiai tampa itin trapūs. Racionalumas net jei jis ir komunikacinis, konvencionalus, neturintis metafizinès pretenzijos negali tapti tuos santykius vienijančiu, socialinio gyvenimo daugialypumą sukontroliuojančiu pagrindu. Autonomiška sutarimų link kreipianti racionali komunikacija valdymo mediju formuojamoje viešybejje $^{38}$ nuolat iškraipoma įvairių galios praktikų, neiveikiamu racionalios refleksijos judesiu. Šios praktikos vis išsiveržia kaip sutarimo galimybes, tapatumus skaldančios skirtys. Racionalus komunikacinis dialogas čia pasirodo kaip imitacija, trapi priedanga, neatlaikanti šiu išsiveržimų. Tokiame kontekste pakertami ir demokratijos santvarkos, grịstos socialiniu harmoningo dialogo principu, pamatai. Demokratija, susipynusi su rafinuotais manipuliaciniais galių žaidimais, vis labiau tampa fasadu, savotišku spektakliu, savęs pačios parodija, slepiančia neišsprendžiamas įtampas. Tai skatina prabilti apie postdemokratiją ${ }^{39}$.

Postdemokratinių itampų kontekste, praradus tikejimą galimybe pozityviai susišnekèti ar netgi šnekètis, iškyla re- liatyvizmo, savidestruktyvaus fragmentizmo grèsmè, kuri ardo socialinius santykius iš vidaus, atverdama pavojingas chaoso erdves. Kita vertus, o gal šios erdvès galètų būti gundančios, skatinančios meniškai mėgautis jomis? Ir vis dèlto ką reikštu pasilikti tokioje dispersiškoje skirčių būklëje? Turint omenyje, kad socialiniame kontekste interpretacijos visuomet susipynusios su galios principu, galima tarti, kad tai reikštų nevaldomus interpretacinius konfliktus, grąžinančius ị leviatanišką būklę.

Todèl net ir postmoderniajame postdemokratiniame kontekste vienaip ar kitaip vis stengiamasi išvengti šio destruktyvaus irimo nepasitenkinant anarchiška socialinių santykių savieiga ieškant šių dienų pasaulèvaizdi atitinkančio socialinès tvarkos modelio. Dèl to nesiliaujama kalbèti apie tam tikrus socialinius sutarimus, kad ir likvidžius, integruojant juos su skirties mąstymu - ižzvelgiant skirti tokiuose susitarimuose ar, tiksliau, bandymuose tartis, suvokiant, kad jie netrukus bus perinterpretuojami.

Falzoniškai ${ }^{40}$ interpretuojant M. Foucault teorija, joje aptinkama postmoderni atvira dialogo samprata, kuri pasirodo kaip alternatyva vien daugybès mažuju pasakojimu fragmentizmui. Remiantis šia koncepcija, socialiniame gyvenime mes egzistuojame dialoge: Foucault skelbta žmogaus mirtis, ,igalina mus suvokti save kaip neišvengiamai egzistuojančius dialoge ${ }^{\prime \prime 41}$. Dialogas čia suprantamas plačiai - kaip i̇sitraukimas i socialinius santykius - ne „normatyviai, kaip idealas, kuris turi būti igyvendintas. Verčiau tai yra gyvenimo faktas. Mes esame neišvengiamai užklumpami dialoge ${ }^{\prime 42}$. 
Tai yra kontaktas su kitais, nuolatinè, neišvengiama tarpusavio sąveika: socialiniame gyvenime mes negalime atmesti tam tikrų bendrumo, kaip socialinès sąveikos, formų, negalime likti atomizuotų skirčių būklejje. Taip esame įtraukiami i toki dialoga, kuris nuolatos vyksta socialinèje sferoje. Mes egzistuojame šitoje dialogo sferoje, priimdami tam tikrus sprendimus apie kitus, sueidami i tam tikrus socialiai neišvengiamus likvidžius bendrumus ir iš jų išeidami, kurdami vienokias arba kitokias socialines tvarkas ir jas perkurdami.

Toks dialogas jau nebėra uždaras, saugantis nuo dominavimo jègų (kaip Habermaso teorijoje), jis pasirodo integraliai susipynęs su skirtimi, o ne siekia atsiriboti nuo jos savo racionalioje idealybejje: kad ir koks brandus būtų kritinis racionalumas, jis vis dèlto nepajègus iveikti patirtinių prielaidų, iš kurių kyla neredukuojami skirtingumai. Taigi atskirybès, atsitiktinumai čia neasimiliuojami į universalumo, privalomumo dèsnius. Tai dinamiškas, provokuojantis dialogas, palaikantis nuolatinę santykio su kitu itampą: „Kad ir kiek stengtumèmès prisijaukinti pasauli, jo niekada iki galo neperprasime ir nesusisteminsime. Jis visada priešinasi ir pranoksta mūsų supratimą. Siekdami tvarkyti pasauli, mes neišvengiamai susiduriame su kitu, kuris vengia mūsų kategorijų, tačiau gali veikti bei formuoti mus. "43 Foucault tipo dialogas atviras nenumatomam kitam, kuris išsprūsta iš mūsų suvokimo gniaužtų ir teigia save priešindamasis, kuris meta iššūki, suardo ir transformuoja ittvirtintus tapatumus, kuris gali bet kada sukrèsti, apversti aukštyn kojom esamą socialinę tvarką...
Tokio pobūdžio Foucault socialinis dialogas gerokai artimesnis šiandieninei postdemokratijai, pripažistančiai kito neredukuojamumą i tą pati ir įsisąmoninusiai to kito valią dominuoti galios santykių kontekste. Jis igalina išskleisti interpretacinius skirtumus, skirtingus, kitus balsus, nesuprastinamus i joki tapatuma, neištirpdomus jokiame konsensuso balse. Toks dialogas pamažu virsta „santykių su kitu abipusiškumą" išsaugančia "tarpusavio kova"44.

Taigi mes įmetami į neišsprendžiamų interpretacinių konfliktų erdvę, atveriančią pavojingą nestabilumą, nuolatinę kaita, kuri igalina produkuoti vis naujas socialines tvarkos formas, suprantant, kad jos tèra sąlyginiai konstruktyvistiniai dariniai, atviri dekonstrukcijai ir rekonstrukcijoms. Skatina atsiduoti šiam kūrybiniam transgresyviam aktyvumui, verčiančiam nuolat peržengti esamas ribas ir nežadančiam jokio galutinio taško.

Tačiau gali kilti klausimas: tai kam iš viso įvedamas tokio dialogo konceptas i šią nesuvaldomą skirčių bei galių žaismę, jei jis neuždaro, - greičiau tik padeda atverti šią nekontroliuojamų galios santykių Pandoros skrynią?

Toks dialogas tik padeda išvengti tam tikrų dominavimo, galios santykių suabsoliutinimo, suvokiant, kad pačių galių santykių nusikratyti neįmanoma. Neišsprendžiama itampa tarp dialogo ir galios santykių: viena vertus, dialogu mes stengiamès tuos santykius kontroliuoti ar bent kiek sušvelninti, kita vertus, jie nuolat meta iššūki tam dialogui ir ji transformuoja. Tai ittampa tarp pastangos pasiekti tam tikrus sutarimus ir juos trikdančių galios santykių, tarp dialogo ir skirties, tarp pokalbio ir kovos. Šiandien 
mes egzistuojame šioje ịtampoje, balansuodami tarp socialinès tvarkos, organizacijos ir dekonstruojančios kito galios.

Foucault socialinè teorija pasirodo persmelkta šios ittampos. Ji susieja šitą teoriją su N. Davey'aus neramaus supratimo ${ }^{45}$ apnikta hermeneutika, išlaisvinančia savo dekonstrukcini potenciala, taip apsaugančia nuo nihilistinio sąstingio: „Priešingai nihilizmo sąstingiui, hermeneutikos supratimo vitališkumą kuria jo konstituciniam buvimui tarp būdingos itampos palaikymas. Supratimas yra iš prigimties nestabilus. [...] Supratimo gyvenimo momentą garantuoja neišsprendžiama jo buvimo tarp itampa." 46

Tai produktyvi, gyvybinga itampa, skatinanti išlikti budrius, nepasiduoti jokioms „realaus“ išlaisvinimo iš „,klaidingü" tikejjimų iliuzijoms. Raginanti isisąmoninti, kad nèra tikrų ar klaidingų tikejjimu - tik sąlyginiai, nuo aplinkybių priklausantys sutarimai, kad klaidžiodami interpretaciju interpretaciju klystkeliais, priimame tik vis kitus tikejjimus, nežadančius jokio galutinio išlaisvinimo.

Šiame kontekste Habermaso idealaus dialogo, o kartu ir tobulos demokratijos utopija galbūt galètų būti regima kaip tas Derrida dekonstrukcijos perimtas leviniškasis Visiškai Kitas, kuris visuomet dartik-turi-ateiti, bet niekuomet neateis. Produktyvu būtų vien judèti šio ateitiškumo toliuose regimos vizijos link. Tačiau šiandieniniame socialiniame kontekste, regis, judama visai priešinga kryptimi...

\section{IŠVADOS}

Šiandien socialinį ,,nihilistini pašaukimą" (G. Vattimo) pajutusi hermeneutika atsisako icentrinès orientacijos i bendrą dialogiškai pasiekiamą supratimą ir universalias tiesas. Todèl ir hermeneutinè dialogo samprata, veikiama išcentrinančių galių, plečiasi: nuo griežto esencialaus i̇sitikinimo, kad dialogu būtina pasiekti aiškius bendrus sutarimus, galutines uždaras tiesas, judama prie dialogo kaip atviro, dinamiško santykio su kitu, kuriame svarbiausia - būti pokalbyje, bet ne būtinai sutarti arba pasiekti tik likvidžius sutarimus. Tokia besikeičianti dialogo samprata reikšmingai atsispindi socialiniame kontekste, kuriame skleidžiasi intersubjektyvi etika.

Socialineje plotmèje produktyvi hermeneutinè intersubjektyvi sprendimo eti$k a$, balansuojanti tarp radikaliu sprendi- muc ir absoliutaus svetingumo: viena vertus, raginama nepriimti radikalių sprendimu - kitas traktuojamas ne objektiškai, o dialogiškai, kita vertus, neliekama neapsisprendžiamumo būklëje asimetriškai atsidavus kitam. Ši etika skleidžiasi kaip dinamiškas, nepretenduojantis i užtikrintumą dialogas. Jis socialinëje politinèje plotmèje reiškiasi kaip likvidūs, perinterpretuojami sutarimai.

Habermaso komunikacinio racionalumo teorija patiria savo ribas, nes užmerkia akis prieš darnų susišnekejjimą nuolat trikdančius galios santykius, idealiai tikèdama, kad tai, kas netelpa i šio susišnekèjimo rèmus, tèra nereikšminga konsensuso liekana, kurią galima įveikti maksimaliai išskaidrinta racionalia komunikacija, dialogu, vykstančiu tarp brandžiu asmenybių. Šiandieniame socia- 
liniame kontekste toks siekis pasirodo neigyvendinamas, kaip ir su juo siejama ideali demokratija.

Šiandien atsiduriame postdemokratinių itampuc kontekste, kur sunku ne tik pozityviai susišnekèti, bet kartais ir iš viso šnekètis. Tokiame kontekste iškyla reliatyvizmo, savidestruktyvaus fragmentizmo grèsmè, ardanti socialinius santykius iš vidaus. M. Foucault teorijoje aptinkama postmoderni atvira dialogo samprata yra tokio fragmentizmo alternatyva. Suvokiama, kad dialogas tik padeda sušvelninti dominavimo, galios santykius, bet ne jų atsikratyti. Atveriama neišsprendžiama ittampa

\section{Literatūra ir nuorodos}

1 Jean-Francois Lyotard, Postmodernus būvis: Šiuolaikinị žinojima aptariant. Vilnius: Baltos lankos, 1993.

2 Vattimo Gianni, The Nihilistic Vocation of Hermeneutics. Beyond Interpretation: The Meaning of Hermeneutics for Philosophy. David Webb (transl.). Stanford, California: Stanford University Press, 1997, p. 1-14.

3 Nicholas Davey, Unquiet Understanding: Gadamer's Philosophical Hermeneutics. The United States of America: State University of New York, 2006, p. xii.

4 P. Michelfelder; Richard E. Palmer. Dialogue $\mathcal{E}$ Deconstruction: The Gadamer - Derrida Encounter. Albany: State University of New York Press, 1989, p. 2.

5 Vytautas Rubavičius, Postmodernusis diskursas: filosofine hermeneutika, dekonstrukcija, menas. Vilnius: Kultūros, filosofijos ir meno institutas, 2003, p. 114.

6 Nicholas Davey, 2006, p. 5.

7 Jacques Derrida, Of Hospitality. Stanford: Stanford University Press, 2000, p. 25.

8 Ten pat.

9 Mark W. Westmoreland, Interruptions: Derrida and Hospitality. Kritike, Vol. 2, No. 1, 2008, p. 4.

10 Tomas Kavaliauskas, Žmogaus teisių tragedija po Nicos palmių šakelèmis. Kultūros barai, tarp dialogo ir galios santykių: viena vertus, dialogu mes stengiamès tuos santykius kontroliuoti ar bent kiek sušvelninti, kita vertus, jie nuolat meta iššūki tam dialogui ir ji transformuoja. Tai itampa tarp pastangos pasiekti tam tikrus sutarimus ir juos trikdančiu galios santykiuc, tarp dialogo ir skirties, tarp pokalbio ir kovos.

Šiandien mes egzistuojame šioje įtampoje balansuodami tarp socialinès tvarkos, organizacijos ir dekonstruojančios kito galios. Tai produktyvi, gyvybinga itampa, skatinanti išlikti budrius, nepasiduoti jokioms ,realaus“ išlaisvinimo iš ,klaidingų“ tikẻjimų iliuzijoms.
Nr. 7-8, 2016.Taip pat šis tekstas prieinamas adresu: http://www.delfi.lt/news/ringas/lit/t-kavaliauskas-zmogaus-teisiu-tragedija-po-nicospalmiu-sakelemis.d?id=72043604

11 Tomas Kavaliauskas, Civilizacijos nusižudo pačios. Kultūros barai, Nr. 10, 2016, p. 17.

12 Timothy Garton Ash, Islam in Europe. The New York Review of Books, LIII, 2006.

13 Algirdas Degutis, Atviros visuomenès spąstai. Athena 4, 2008, žr.: http://versijos.lt/atviros-visuomenes-spastai/.

14 Timothy Garton Ash, Ian Buruma, Better Pascal than Pascal Bruckner. 2007, žr.: http://www.signandsight.com/features/1166.html. Taip pat: Pascal Bruckner, A reply to Ian Buruma and Timothy Garton Ash. 2007, žr.: http://www.signandsight.com/features/1263.html.

15 Algirdas Degutis, Atviros visuomenès spastai.

16 Michel Houellebeck, Pasidavimas. Vilnius: Kitos knygos, 2015.

17 Arnoldo J. Toynbee minties reinterpretacija Leonido Donskio tekste Leonidas Donskis: pasidavimas ir Europos savižudybė? Žr.: http://www.15min.lt/ naujiena/aktualu/komentarai/leonidas-donskispasidavimas-ir-europos-savizudybe-500-568557

18 Richard Kearney, Strangers and Others: From Deconstruction to Hermeneutics. Critical Horizons. Leiden: Koninklijke Brill NV, 2002, p. 14. 
19 Ten pat, p. 9.

20 Ten pat, p. 13.

21 Fred Dallmayr, Hermeneutics and Deconstruction: Gadamer and Derrida in Dialogue. Diane P. Michelfelder \& Richard E. Palmer (ed., transl.). Dialogue \& Deconstruction: The Gadamer Derrida Encounter. Albany: State University of New York Press, 1989, p. 93-102.

22 Kearney Richard, 2002, p. 30.

23 Regina Kreide, The silence of political liberalism, žr.: http://www.eurozine.com/articles/2016-1004-kreide-en.html

24 Why are thousands of Germans protesting and who are Pegida? Žr.: http://www.bbc.co.uk/newsbeat/ article/30694252/why-are-thousands-of-germans-protesting-and-who-are-pegida

25 Kenan Malik, A Merkel attack on multiculturalism, žr.: http://www.eurozine.com/articles/2011-0221-malik-en.html

26 Navidas Kermani, Vokietijos publicistas: Europa gerai nebefunkcionuoja ir byra. Žr.: http://www.15min.lt/ naujiena/aktualu/pasaulis/vokietijos-publicistaseuropa-gerai-nebefunkcionuoja-ir-byra-57-684633

27 Valeria Korablyova, Pariahs and parvenus? Žr.: http://www.eurozine.com/articles/2015-11-26-korablyova-en.html

28 Richard Rorty, Contingency, irony, and solidarity. Cambridge University Press, 1989.

29 Richard Kearney, 2002, p. 29.

30 Jack Mendelson, The Habermas-Gadamer Debate. New German Critique 18, 1979, p. 44-73.
31 Jürgen Habermas, Komunikacinis, arba į subjektą atgręžtas, protas - kita išeitis iš subjektinès filosofijos. Modernybès filosofinis diskursas. Vilnius: Alma littera, 2002, p. 332-366.

32 Jürgen Habermas, Fœssel Michaël, Critique and communication: Philosophy's missions: A conversation with Jürgen Habermas, žr.: http://www.eurozine.com/articles/2015-10-16-habermas-en.html

33 Ten pat.

34 Ten pat.

35 Pierre Bourdieu, Language and symbolic power. Cambridge; Oxford: Polity Press, 1994.

36 Ten pat.

37 Ernesta Molotokienè, Jürgenas Habermas: komunikacijos (ne)galimybė medijuotoje visuomenèje, $\log o s$ 73, 2012, p. 18.

38 Ten pat.

39 Jau seniai kalbama apie demokratijos išsisemima, bet šiandien ši tema yra itin aktuali. Pavyzdžiui, tinklalapyje eurozine paskelbtas reprezentatyvus straipsnių rinkinys pavadinimu ,Demokratijos pabaiga“, žr.: http://www.eurozine.com/ comp/focalpoints/democracy.html

40 Christopher Falzon, Foucault and Dialogue. Foucault and Social Dialogue: Beyond Fragmentation. USA and Canada: Routledge, 1998.

41 Ten pat, p. 4.

42 Ten pat, p. 6.

43 Ten pat, p. 4.

44 Ten pat, p. 7.

45 Nicholas Davey, 2006.

46 Ten pat, p. 184. 